УДК 347.97

DOI https://doi.org/10.32837/pyuv.v2i3(28).361

\author{
Д. В. Крилов \\ доктор економічних наук, \\ докторант \\ Науково-дослідного інституту публічного права
}

\title{
ПРАВОВЕ РЕГУЛЮВАННЯ ПРАВОВИХ ВІДНОСИН У СФЕРІ РЕАЛІЗАЦІЇ ДЕРЖАВНОЇ ПОДАТКОВОЇ ПОЛІТИКИ: АДМІНІСТРАТИВНО-ПРАВОВИЙ АСПЕКТ
}

Вітчизняний досвід та зарубіжна практика переконливо демонструють вплив оподаткування на всі сфери суспільного життя, зокрема на соціальний та економічний аспекти. Через реалізацію податкової політики держава здатна ефективно стимулювати господарську діяльність, формувати сприятливі умови для розвитку пріоритетних галузей економіки, регулювати наповнення бюджету.

Сплата податків більшою чи меншою мірою стосується кожної людини. Необхідність сплачувати податки не залежить від конкретних обставин, тобто $є$ абсолютним обов'язком Так, відповідно до ст. 67 Конституції України «кожен зобов'язаний сплачувати податки і збори в порядку і розмірах, встановлених законом. Усі громадяни щорічно подають до податкових інспекцій за місцем проживання декларації про свій майновий стан та доходи за минулий рік у порядку, встановленому законом» [1].

На сучасному етапі розвитку України, що, з одного боку, характеризується процесами євроінтеграції, а з іншого - станом зовнішньої військової агресії, якісне правове регулювання податкових правових відносин набуває особливої актуальності та важливості.

У ст. 10 Господарського кодексу України закріплено, що податкова політика має бути спрямована на забезпечення економічно обгрунтованого податкового навантаження на суб'єктів господарювання, стимулювання суспільно необхідної економічної діяльності суб'єктів, а також дотримання принципу соціальної справедливості та конституційних гарантій прав громадян при оподаткуванні їх доходів [2].

Виділення адміністративно-правового аспекту у регулюванні правових відносин, що виникають під час втілення податкової політики, та розкриття його сутності буде сприяти забезпеченню пріоритетності прав платників податків, балансуванню інтересів учасників податкових правовідносин, пошуку ефективних механізмів своєчасного формування публічних грошових фондів та захисту національних інтересів.

Особливості регулювання правових відносин у сфері реалізаціїдержавної податкової політики досліджували такі провідні науковці, як В.Б. Авер'янов, Г.В. Атаманчук, О.В. Бакун, О.М. Бандур- ка, О.С. Башняк, А.О. Беспалова, Ю.П. Битяк, С.В. Бризгалін, Д.В. Вінницький, Л.К. Воронова, В.М. Гаращук, О.В. Джафарова, С.В. Запольський, В.В. Зуй, Р.Ю. Ісаншина, М.В. Карасьова, В.А Кашин, О.М. Козирін, А.І. Крисоватий, М.П. Кучерявенко, І.А. Майбуров, С.Г. Пепеляєв, М.О. Перепелиця, В.М. Пушкарьова, Л.А. Савченко, М.В. Тарасюк, В.І. Теремецький, С.О. Шатрава, В.К. Шкарупа, Є.А. Ровінський, Н.С Хатнюк, Н.І. Хімічева, А.Ф. Цимбалюк, С.Д. Ципкін, Т.Ф. Юткін тощо.

Проте маємо відзначити, що розмежувати адміністративне право і комплексні галузі права досить складно. Наприклад, механізм співвідношення адміністративного і податкового права такий, що більшу частину відносин, які формують предмет останнього, врегульовано нормами адміністративного права та за допомогою притаманних йому правових засобів. З огляду на це сутність адміністративно-правового аспекту в регулюванні правових відносин у сфері реалізації державної податкової політики потребує подальшого розкриття, а обрана тема дослідження набуває своєї актуальності.

Дана наукова робота має на меті розкриття сутності правової природи регулювання правових відносин у сфері реалізації державної податкової політики. Для цього необхідно розглянути склад податкового законодавства України, охарактеризувати особливості, співвідношення і спрямованість публічно-сервісних, правоохоронних та юрисдикційних правовідносин, що складаються під час забезпечення державною владою реалізації податкової політики в Україні.

Розглядаючи правові відносини, що існують у сфері реалізації державної податкової політики, зазначимо, що доцільно звернути увагу на правові норми, з яких складається податкове законодавство нашої держави. Стаття 3 Податкового кодексу України містить такий їх перелік: Конституція України; Податковий кодекс України; Митний кодекс України, інші закони з питань митної справи у частині регулювання правовідносин, що виникають у зв'язку з оподаткуванням митом операцій з переміщення товарів через митний кордон України; чинні міжнародні договори, згода на обов'язковість яких надана Верховною 
Радою України, що ними регулюються питання оподаткування; нормативно-правові акти, прийняті на підставі та на виконання (Податкового) Кодексу та законів з питань митної справи; рішення Верховної Ради Автономної Республіки Крим, органів місцевого самоврядування з питань місцевих податків та зборів, прийняті за правилами, встановленими Податковим кодексом [3].

Як відзначає В. Теремецький, світова та вітчизняна практика свідчать, що податкові відносини в більшості країн світу регулюються кодифікованими актами (і Україна у цьому відношенні не є виключенням). Податковий кодекс України, як i білоруський, визначає сферу дії самого Податкового кодексу, а не сферу податкових відносин загалом. Так, ст. 1 Податкового кодексу України визначає коло суспільних відносин, що виникають у сфері справляння податків і зборів та підпадають під сферу його дії (регулювання). Проте аналіз положень цієї статті дозволяє зробити висновок, що деякі аспекти податкових відносин ними не охоплюються (зокрема, встановлення (введення) податків, оскарження рішень і дій податкових органів та їх посадових осіб тощо). Натомість вводиться такий термін, як «порядок адміністрування», хоча його зміст у кодексі не розкривається. В. Теремецький підкреслює, що не всі наявні податкові правовідносини повністю потрапляють у сферу податково-правового регулювання. Деякі з них становлять предмет інших підгалузей фінансового права і навіть інших правових утворень. Так, в рамках групи правовідносин щодо справляння податків і зборів відносини, які забезпечують примусове стягнення податків, зборів та пені з фізичної особи й організації, що здійснюються в судовому порядку, регламентуються цивільним процесуальним чи господарським процесуальним правом [4, с. 117-118].

Зі свого боку П. Гега та Л. Доля зазначають, що податкові правовідносини є формою вираження економічних, політичних та інших відносин $[5$, c. 10$]$.

Н. Хатнюк, аналізуючи дане питання, робить висновок про те, що оподаткування тісно переплітається 3 усіма сферами правової дійсності українського суспільства, тому цілком логічно, що правове регулювання податкових правових відносин відображається у великій кількості нормативно-правових актів. Водночас велика кількість правових джерел ускладнює розуміння окремих податкових правових норм та може сприяти неоднозначному їх трактуванню як платниками податків, так і посадовими особами контролюючого органу [6, с. 181].

Отже, беручи до уваги досить широкий спектр питань, 3 якими перетинається сфера оподаткування, вважаємо, що для подальшого дослідження доцільним буде розглянути зміст більш узагальненого поняття, тобто поняття «правові відносини».

На думку М. Цвіка, правові відносини - це відносини між людьми, які є юридичним вираженням економічних, політичних, сімейних, процесуальних та інших суспільних відносин, де одна сторона на основі правових норм вимагає від іншої виконання певних дій або утримання від них, а інша сторона зобов'язана виконати ці вимоги [7, с. 336].

О. Скакун вважає, що норми права і правовідносини є взаємопов'язаними, адже право може діяти лише тоді, коли визначеним подіям або діям надається характер юридично значущих фактів (актів), що ставлять людей у становище сторін правовідносин, які мають взаємозалежні суб'єктивні права і юридичні обов'язки. Отже, правовідносини є об'єктивною формою реалізації прав і обов'язків. 3 огляду на це правовідносини розглядаються як врегульовані нормами права i забезпечувані державою вольові суспільні відносини, що виражаються в конкретному зв'язку між правомочними (носіями суб'єктивних прав) i зобов'язаними (носіями обов'язків) суб'єктами [8, с. 382-384].

Узагальнюючи слова перелічених науковців, ми доходимо висновку про те, що правовідносини в сфрері регулювання податкової політики є різновидом суспільних відносин, які врегульовані нормами публічного права. При цьому спрямованість правового регулювання у сфері податкової політики включає в себе публічно-сервісну, правоохоронну та юрисдикційну діяльність держави.

Як зазначає В. Авер'янов, публічно-сервісна діяльність - це діяльність відповідних державних і недержавних органів щодо забезпечення в ході їхніх взаємостосунків з населенням, конкретними фізичними та юридичними особами умов, за яких останні здатні ефективно реалізовувати й захищати свої права, свободи та законні інтереси [9, с. 269].

Б. Гук пише, що введення в правовий обіг такого поняття, як «публічно-сервісна діяльність», вже давно викликає дискусії в наукових колах, оскільки така діяльність грунтується на конституційному положенні соціальної спрямованості держави тає змістом діяльності держави, їїобов'язком щодо забезпечення прав і свобод людини [10, с. 119].

Звертає на себе увагу з цього приводу наукова позиція О. Джафарової, яка пропонує для визначення розглядуваної категорії зосередитися на аналізі категорій більш загального порядку, таких як «держава», «права і свободи громадян» та «механізм забезпечення прав і свобод громадян», оскільки взаємозв'язок останніх є центральним для юридичної науки. В основі організації та функціонування сучасної Української держави лежить суспільний договір, який передбачає, що держава утворюється волевиявленням вільних i 
незалежних осіб та зобов'язується всіляко сприяти реалізації прав людини, а у разі їх порушення держава мусить захищати останні. Інша сторона суспільного договору також має певні зобов'язання, серед яких є сплата податків, дотримання встановлених правил поведінки, обов'язок захищати цілісність держави тощо. Слід зауважити, що при цьому особам надається пріоритет і можливості реалізувати належні їм права, зокрема й у відносинах з публічною адміністрацією. Саме в такому підході розкривається сучасне уявлення про державу як про інституцію, що надає певні послуги особам, які, так би мовити, їх замовляють. Коло цих послуг прямо випливає з публічних функцій держави, які є змістовим наповненням, підгрунтям для виокремлення та закріплення конкретних прав і обов'язків суб'єктів відповідних відносин [11, с. 56-57]. Публічно-сервісна діяльність держави в сфері здійснення податкової політики включає в себе, наприклад, адміністрування податків, видачу дозвільних документів тощо.

Ю. Шемшученко зазначає, що правоохоронна діяльність - це вид державної діяльності, яка здійснюється з метою охорони права спеціально уповноваженими органами шляхом застосування юридичних заходів впливу суворо відповідно до закону і за неухильного дотримання встановленого ним порядку [12]. У сфері здійснення державної податкової політики правоохоронна діяльність передбачає, наприклад, проведення перевірок виконання законів та інших нормативно-правових актів. Як зазначає Ю. Битяк, до адміністративних засобів правоохоронного характеру належать різні форми і методи здійснення контролю і нагляду за дотриманням законності і дисципліни у сфері державного управління, а також застосування передбачених законом засобів виховного і примусового впливу. Вони використовуються для охорони суспільного ладу України, власності, соціально-економічних, політичних та особистих прав і свобод громадян, прав і законних інтересів підприємств, установ і організацій, встановленого порядку управління, державного і громадського порядку, зміцнення законності, попередження правопорушень і боротьби з ними, виховання громадян у дусі точного дотримання Конституції і законів України [13, с. 26].

C. Kоміссаров стверджує, що під адміністративно-юрисдикційною діяльністю необхідно розуміти врегульовану законом діяльність уповноважених державних органів, органів місцевого самоврядування, їх посадових та службових осіб, спрямовану на здійснення проваджень у справах про адміністративні правопорушення, виконання постанов про накладення адміністративних стягнень, а також застосування заходів адміністративного попередження та припинення таких правопорушень з метою охорони прав і сво- бод громадян, власності, конституційного ладу України, прав і законних інтересів підприємств, установ і організацій, встановленого правопорядку, зміцнення законності, запобігання правопорушенням, виховання громадян у дусі точного i неухильного дотримання Конституції і законів України, поваги до прав, честі й гідності людини, до правил співжиття, сумлінного виконання своїх обов'язків, відповідальності перед суспільством [14, с. 105-106]. Л. Анохіна розглядає поняття «адміністративна юрисдикція» у двох таких аспектах: статичному (як сукупність повноважень суб’єкта адміністративної юрисдикції) та функціонально-динамічному (як особливий вид правозастосовної діяльності) [15]. Ю. Битяк відмічає, що роль адміністративної відповідальності у боротьбі з правопорушеннями постійно зростає, збільшується кількість складів адміністративних правопорушень, більш суворими стають санкції за проступки. Встановлюється відповідальність за діï, які раніше взагалі не належали до правопорушень, наприклад, порушення податкового законодавства тощо [16, с. 170].

Аналізуючи поняття правового регулювання та правових відносин, слід відзначити думку В. Авер'янова, який наголошував на тому, що правовідносини належать до фундаментальних категорій науки адміністративного права, оскільки саме в правовідносинах таке право існує, діє, живе. У них найбільш рельєфно відображається специфіка методу адміністративно-правового регулювання суспільних відносин [17, с. 175]. 3 огляду на це правильним і необхідним вважаємо встановлення кола тих суспільних відносин, які врегульовані нормами адміністративного права, оскільки це дозволить точно виявити призначення методів цієї галузі права, дослідити весь потенціал їх регулюючого впливу та визначити рівень їхної ефективності [18, с. 186].

Ю. Битяк зазначає, що адміністративно-правові відносини - це суспільні відносини у сфері державного управління, учасники яких виступають носіями прав і обов'язків, урегульованих нормами адміністративного права. Можна відзначити такі особливості адміністративно-правових відносин:

1) в адміністративно-правових відносинах права і обов'язки потребують для свого задоволення відповідних дій виконавчо-розпорядчого характеру;

2) умовою виникнення адміністративно-правових відносин $є$ участь у них обов'язкового суб'єкта (держави);

3) адміністративно-правові відносини можуть виникати з ініціативи кожної із сторін незалежно від волевиявлення другої сторони;

4) спори між сторонами адміністративно-правових відносин, як правило, вирішуються в адміністративному порядку; 
5) адміністративно-правові відносини, що виникають між органами виконавчої влади та іншими учасниками адміністративного права, не завжди є відносинами, що здійснюються за методом влади та підпорядкування;

6) порушення однією із сторін адміністративно-правових відносин вимог адміністративно-правової норми тягне за собою юридичну відповідальність [16, с. 59-60].

3 огляду на викладене можна стверджувати, що відносини у сфері реалізації державної податкової політики в Україні достатньо чітко окреслені та врегульовані на рівні законодавства.

Проте податкова сфера має занадто тісні взаємозв'язкизіншими галузями суспільногожиття та вплив на них. Для ефективного забезпечення пріоритетності прав платників податків та пошуку дієвих механізмів своєчасного формування публічних грошових фондів необхідно уточнити та розкрити сутність правовідносин, які виникають у сфері реалізації державної податкової політики.

Правове регулювання у сфері податкової політики включає в себе публічно-сервісну, правоохоронну та юрисдикційну діяльність держави, яка має на меті задоволення прав і законних інтересів людини. Така діяльність полягає у забезпеченні високого рівня якості життя людей на всій території України, а також передбачає досягнення оптимального балансу між наповненням бюджету та підтримкою умов економічного зростання і підвищення суспільного добробуту. Загалом сфера податків впливає на забезпечення національних інтересів України. Отже, відносини, які виникають у сфері оподаткування, мають вкрай важливе значення.

Відносини у сфері регулювання державної податкової політики мають такі ознаки: ці відносини передбачають обов'язкову участь держави, потребують для свого задоволення відповідних дій виконавчо-розпорядчого характеру, можуть виникати з ініціативи кожної із сторін незалежно від волевиявлення іншої сторони; спори між сторонами правових відносин, як правило, вирішуються в адміністративному порядку, а порушення однією із сторін правових відносин вимог правової норми тягне за собою юридичну відповідальність; відносини, що виникають між органами виконавчої влади та іншими учасниками правових відносин у сфері здійснення державної податкової політики, не завжди є відносинами, що здійснюються за методом влади та підпорядкування.

3 огляду на аналіз відносин, що виникають у сфері регулювання державної податкової політики, можна впевнено стверджувати, що за своєю сутністю вони подібні до характеристик адміністративно-правових відносин. Отже, базою правового регулювання державної податкової політики $€$ адміністративно-правові норми.

\section{Jimepamypa}
1. Конституція України : Закон України від 28.06.1996 p. № $254 \kappa / 96-B P$. URL: https://zakon.rada.gov.ua/laws/main/254k/96-BP.

2. Господарський кодекс України : Закон України від 16.01.2003 p. № 436-IV. URL: https://zakon.rada.gov.ua/laws/main/436-15.

3. Податковий кодекс України : Закон України від 02.12 .2010 p. № 2755-VI. URL: https://zakon.rada.gov.ua/laws/show/2755-17\#n8773.

4. Теремецький B.I. Сутність та ознаки податкових правовідносин в аспекті сучасного податкового права. Науковий вісник львівського державного університету внутрішніх справ. 2012. № 1. С. 115-126. URL: http://www.lvduvs.edu.ua/documents_pdf/visnyky/ nvsy/01_2012/12tvispp.pdf.

5. Гега П.Т., Доля Л.М. Основи податкового права : навч. посібник. 3-те вид., випр. і доп. Київ : Знання, КOO, 2003. $302 \mathrm{c}$.

6. Хатнюк Н.С. Правове регулювання податкових правовідносин: стан та перспективи удосконалення. Наше право. 2017. № 2, 2017. С. 177-183. URL: http://nashe-pravo.unesco-socio.in.ua/wp-content/ uploads/2018/07/zhurnal-nashe-pravo-2-2017.pdf.

7. Загальна теорія держави і права : підручник для студентів юридичних спеціальностей вищих навчальних закладів / М.В. Цвік, В.Д. Ткаченко, Л.Л. Богачова та ін. ; за ред. М.В. Цвіка, В.Д. Ткаченка, О.В. Петришина. Харків : Право, 2002. $432 \mathrm{c.}$

8. Скакун О.Ф. Теорія права і держави : підручник. 2-ге видання. Київ : Алерта ; КНТ ; ЦУЛ, 2010. 520 с.

9. Авер'янов В.Б. Вибрані наукові праці / за заг. ред. Ю.С. Шемшученка, О.Ф. Андрійко. Київ : Ін-т держави і права ім. В.М. Корецького НАН України, 2011. 448 с.

10. Гук Б.М. Адміністративні послуги органів публічної влади України: поняття, зміст. Право і суспільство. 2011. № 3. C. 117-121. URL: http://nbuv.gov.ua/ UJRN/Pis_2011_3_25.

11. Джафарова О.В. Щодо розуміння категорії «публічно-сервісна діяльність» Національної поліції. Безпека дорожнього руху: правові та організаційні аспекти : матеріали XI Міжнар. наук.-практ. конф., м. Кривий Ріг, 22 листоп. 2016 р. ; Донец. юрид. ін-т МВС України. Кривий Ріг, 2016. С. 55-58.

12. Правоохоронна діяльність. Вікіпедія: вільна енциклопедія. URL: https://uk.wikipedia.org/wiki/ Правоохоронна_діяльність.

13. Адміністративне право України : підручник для юрид. вузів і фак. / Ю.П. Битяк, В.В. Богуцький, В.М. Гаращук та ін. ; за заг. ред. Ю.П. Битяка. Харків : Право, 2000. 520 с.

14. Коміссаров С. Сутність адміністративно-юрисдикційної діяльності. Науковий часопис Національної академії прокуратури України. 2015. № 3. С. 100-107. URL: http://www.chasopysnapu.gp.gov.ua/chasopys/ ua/pdf/7-2015/komisarov.pdf.

15. Анохіна Л.С. Суб'єкти адміністративної юрисдикції в Україні : автореф. дис. ... канд. юрид. наук : спец. 12.00.07. Харків, 2001. 15 с.

16. Адміністративне право : підручник / Ю.П. Битяк (кер. авт. кол.), В.М. Гаращук, В.В. Богуцький та ін. ; за заг. ред. Ю.П. Битяка, В.М. Гаращука, В.В. Зуй. Харків : Право, 2010.624 с.

17. Авер'янов В.Б. Адміністративне право України. Академічний курс : підручник : у 2-х т. / ред. колегія: В.Б. Авер'янов (голова). Київ : Юрид. думка, 2004. Т. 1 Загальна частина. 2004.584 с.

18. Юровська В.В. Поняття та ознаки адміністративних правовідносин як сфери правового впли- 
ву адміністративно-правових методів. Науковий вісник Херсонського державного університету. Серіл «Юридичні науки». 2016. № 6-2 Т. 1. 2016. С. 185-188. URL: http://www.lj.kherson.ua/2016/pravo06-2/part 1/43.pdf.

\section{Анотація}

Крилов Д. В. Правове регулювання правових відносин у сфері реалізації державної податкової політики: адміністративно-правовий аспект. - Стаття.

Статтю присвячено дослідженню юридичної природи правових відносин, що складаються в процесі реалізації державної податкової політики. Увагу приділено адміністративно-правовому аспекту цих відносин. Розглянуто нормативну базу, на якій грунтується регулювання податкової політики. Відмічено тісний зв'язок даної галузі з усіма сферами правової дійсності суспільства. Проаналізовано поняття «правові відносини» та «правове регулювання». Охарактеризовано зміст правового регулювання податкової галузі через дослідження публічно-сервісної, правоохоронної та юрисдикційної діяльності держави в податковій сфері. Визначено, що правове регулювання у сфері податкової політики включає в себе публічно-сервісну, правоохоронну та юрисдикційну діяльність держави, яка має на меті задоволення прав і законних інтересів людини. Така діяльність полягає у забезпеченні високого рівня якості життя людей на всій території України, а також передбачає досягнення оптимального балансу між наповненням бюджету та підтримкою умов економічного зростання і підвищення суспільного добробуту. Сфера податків впливає на забезпечення національних інтересів України. Отже, відносини, які виникають у сфері оподаткування, мають вкрай важливе значення. Досліджено особливості адміністративно-правових відносин та доведено, що відносини у сфері регулювання державної податкової політики за своєю сутністю $\epsilon$ адміністративно-правовими. Зроблено висновок, що відносини у сфері регулювання державної податкової політики мають такі ознаки: ці відносини передбачають обов'язкову участь держави, потребують для свого задоволення відповідних дій виконавчо-розпорядчого характеру, можуть виникати з ініціативи кожної із сторін незалежно від волевиявлення іншої сторони; спори між сторонами правових відносин, як правило, вирішуються в адміністративному порядку, а порушення однією із сторін правових відносин вимог правової норми тягне за собою юридичну відповідальність; відносини, що виникають між органами виконавчої влади та іншими учасниками правових відносин у сфері здійснення державної податкової політики, не завж- ди є відносинами, що здійснюються за методом влади та підпорядкування.

Ключові слова: державна податкова політика, правові відносини, правове регулювання, публічно-сервісні відносини, адміністративні правовідносини.

\section{Summary}

Krylov D. V. Legal regulation of legal relations in the field of implementation of the state tax policy: administrative and legal aspect. - Article.

The article is devoted to the study of the legal nature of the legal relations that are formed in the process of implementation of the state tax policy. Attention is paid to the administrative-legal aspect of these relations. The regulatory framework on which tax policy regulation is based is considered, and the close connection of this field with all spheres of legal reality of society is noted. The concepts of "legal relations" and "legal regulation" are analyzed. The content of the legal regulation of the tax industry through the study of public service, law enforcement and jurisdictional activities of the state in the tax sphere is characterized. It is determined that legal regulation in the field of tax policy includes public service, law enforcement and judicial activity of the state. Aiming at satisfying human rights and legitimate interests, it aims at ensuring a high standard of quality of life for people throughout Ukraine, as well as enabling an optimal balance to be found between filling the budget and maintaining conditions for economic growth and enhancing social well-being. Ultimately, the sphere of taxes affects the protection of Ukraine's national interests. Thus, relationships that arise in the field of taxation are extremely important. The peculiarities of administrative-legal relations are investigated and it is proved that the relations in the sphere of regulation of the state tax policy are administrative-legal in their essence. It is concluded that relations in the sphere of regulation of the state tax policy have the following features: they imply obligatory participation of the state; require appropriate enforcement actions to meet their needs; may arise at the initiative of either party, regardless of the will of the other party; as a rule, disputes between the parties to a legal relationship are resolved administratively, and a breach by one of the parties to a legal relationship of legal requirements entails legal responsibility; relations that arise between executive authorities and other participants in legal relations in the sphere of state tax policy implementation are not always relations carried out by the method of power and subordination.

Key words: state tax policy, taxes, legal relations, legal regulation, public-service relations, administrative legal relations. 